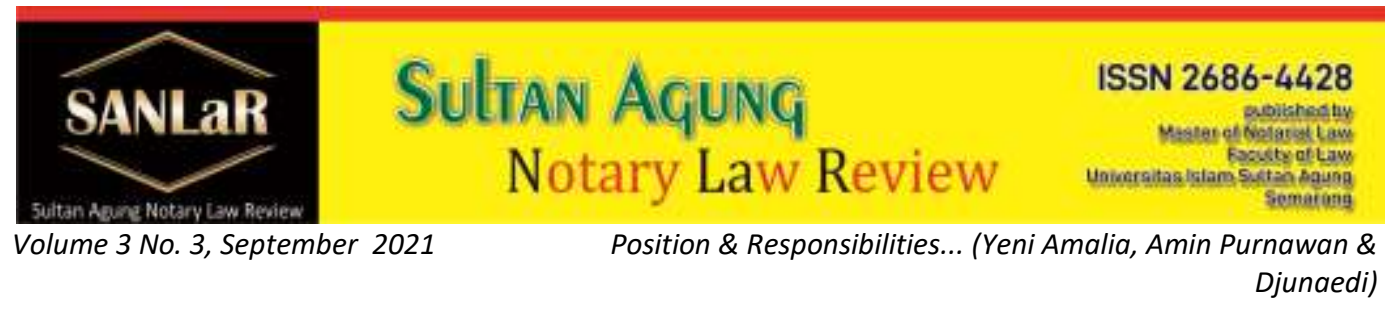

\title{
Position \& Responsibilities of Notaries in Implementing Circular Resolutions of Foreign-Owned Branch Companies
}

\author{
Yeni Amalia*), Amin Purnawan ${ }^{* *}$ and Djunaedi**) \\ ${ }^{*}$ Faculty of Law, Universitas Islam Sultan Agung (UNISSULA) Semarang, E-mail: \\ amaliayeni839@gmail.com \\ ${ }^{* *}$ Faculty of Law, Universitas Islam Sultan Agung (UNISSULA) Semarang, E-mail:
amin.p@unissula.ac.id \\ $\left.{ }^{* * *}\right)$ Faculty of Law, Universitas Islam Sultan Agung (UNISSULA) Semarang. E-mail: \\ djunaedi@unissula.ac.id
}

\begin{abstract}
This study aims to determine the position and responsibilities of a notary in the organs of a Limited Liability Company. There are two types of Limited Liability Company, namely Public Company and Private Company. In a closed company, it is very possible to make circular decisions because the number of shareholders is not as many as a public company. The approach method used in this study is an empirical juridical approach, which is an approach that examines secondary data first and then proceeds with conducting primary data research in the field. Circular decisions are made when it is not possible for a Limited Liability Company to hold a General Meeting of Shareholders or an Extraordinary General Meeting of Shareholders whose provisions can be seen in Article 91 of the UUUP. In Indonesia and even around the world, we are facing a pandemic due to Corona Virus Disease or COVID-19. For a Limited Liability Company whose shareholders are foreigners, a Foreign Investment Limited Company (PMA), of course, cannot come to the position of a Limited Liability Company in Indonesia. So that it is done through video conference whose provisions can be found in Article 77 of the Company Law. Notaries are responsible for making Circular Deeds that do not violate the provisions of the Company Law. The position of the Notary appointed to make the deed of the Circular Decree of the Company can be selected from all over Indonesia. As long as the parties are facing the Notary. However, if a Notary is appointed to follow the process of implementing the Circular Decision, it must be a Notary who has the same position as the Limited Liability Company or may also have a different position but is still in the same province from the position of the Notary appointed to follow the Circular Decision of the Shareholders.
\end{abstract}


Keywords: Circular; Decision; Foreign; Investment; Company; Notary.

\section{Introduction}

A Limited Liability Company is a legal entity that is able to support rights and obligations and is independently responsible for all consequences arising from legal actions that have been carried out. ${ }^{1}$ In a Deed of Establishment of a Limited Liability Company, the amount of capital and the type of capital that will affect the Status of the Limited Liability Company are regulated. Based on the type of capital, the Company is divided into two, namely Domestic Investment (PMDN) and Foreign Investment (PMA). ${ }^{2}$

That of the two types of limited liability company capital, based on Government Regulation Number 8 of 2021, the share of capital distribution is authorized capital, issued capital and paid-up capital. ${ }^{3}$ Based on the existence of two types of capital, the Company affects the system and administration that applies to the company. As in terms of taxation, capital management, dividend distribution, and so on. It can also determine whether a company is owned by a legal entity owned by an Indonesian legal subject or a foreign-owned legal entity domiciled in Indonesia so that it has legal obligations that apply in Indonesia 4 .

As we all know, the whole world is currently experiencing a COVID-19 pandemic. In Indonesia itself, since it was announced for the first time on two thousand and twenty (2-03-2020). ${ }^{5}$ One of the Indonesian Government policies set by the government is to implement several policies such as Large-Scale Social Restrictions (PSBB), which are currently being changed to the Implementation of Community Activity Restrictions (PPKM) for Java-Bali, Micro PPKM, Thickening of Micro PPKM, Emergency PPKM, and the last one is PPKM. PPKM Level 3-4.

\footnotetext{
${ }^{1}$ Budiarto Agus, (2002), Tanggung Jawab Pendirian Perseroan Terbatas, Jakarta: Ghalia, p.106.

${ }^{2}$ Act No. 25 of 2007 concerning Investment

${ }^{3}$ Government Regulation Number 8 of 2021 concerning the Company's Authorized Capital and Registration of Establishment, Amendment, and Dissolution of Companies that Meet the Criteria for Micro and Small Businesses

${ }^{4}$ A Chuasanga, Ong Argo Victoria. (2019). Legal Principles Under Criminal Law in Indonesia Dan Thailand, Jurnal Daulat Hukum, Vol 2, No 1 (2019) http://jurnal.unissula.ac.id/index.php/RH/article/view/4218 see Alam, Bahrul., \& Khisni, Akhmad. (2020). Legal Protection of Holders of Land Loss Data In The City Land Office of Kendari. JURNAL AKTA: Vol.7, No. 2, 159-164. Retrieved from http://jurnal.unissula.ac.id/index.php/akta/article/view/7963

${ }^{5}$ Ade Irmansyah (2020) "Kronologi COVID-19 di Indonesia", Law Justice, url : https://www.lawjustice.co/artikel/85525/sebenarnya-kapan-virus-corona-pertama-kali-masuk-indonesia/ accessed on March 30, 2021 at 14:21 WIB.
} 
Where people can not be free to move and gather. ${ }^{6}$

In situations and conditions such as this, the decision-making or implementation of the GMS can be replaced by carrying out a Circular Resolution, which is not like the general GMS which requires shareholders to be present at the domicile of a limited liability company. In a Circular Resolution, it is not necessary to gather shareholders and present a Notary at the same domicile ${ }^{7}$. Of course, this still has to comply with the applicable regulations in the Republic of Indonesia.

The provisions regarding this Circular Resolution can be found in Article 91 of the Company Law which reads "Shareholders may also make binding decisions outside the GMS on condition that all shareholders with voting rights agree in writing by signing the relevant proposal." 8 This article explains that, decisions can be made for companies with written approval (it is not stated that they must meet in person in the company's position as in the GMS procedure). This study aims to determine the position and responsibilities of a notary in the organs of a Limited Liability Company as regulated in Act No. 40 of 2007 concerning Limited Liability Companies (UUPT).

\section{Research Methods}

The method approach used in this thesis research is an empirical juridical approach. The research specifications used in writing this thesis are descriptive analytical specifications. The data collection method used by the author in writing this thesis is the approach method and the type of data used. So the technique of collecting data used in writing this thesis is document study, observation and interviews. Data analysis used in writing this thesis is qualitative data analysis.

\section{Results and Discussion}

\footnotetext{
${ }^{6}$ Arrohim, Mohammad B., \& Wahyuningsih, Sri Endah. (2020). Analysis of Judicial Application of Criminal Penalty Against Notary / Land Deed Officials Conducting Making Crime of the Fake Authentic Deed in State Court of Semarang. JURNAL AKTA: Vol.7, No. 2, 183-188. Retrieved from http://jurnal.unissula.ac.id/index.php/akta/article/view/7891 see Deen, Thaufiq., Ong Argo Victoria \& Sumain. (2018). Public Notary Services In Malaysia. JURNAL AKTA: Vol. 5, No. 4, 10171026. Retrieved from http://jurnal.unissula.ac.id/index.php/akta/article/view/4135

${ }^{7}$ Ong Argo Victoria, (2018) Waqf Al-Nuqūd In Indonesia (In Law Perspective), Jurnal Pembaharuan Hukum Vol 5, No 1 Universitas Sultan Agung, http://jurnal.unissula.ac.id/index.php/PH/article/view/2999 see Sukarmi, S., \& Victoria, A. (2018). Cash Waqf in Sustaining Of Indonesian Society "In Legal \&amp; Economic Perspective". ALITQAN: JOURNAL OF ISLAMIC SCIENCES AND COMPARATIVE STUDIES, 2(1), 83-97. https://doi.org/10.31436/al-itqan.v2i1.43

${ }^{8}$ Article 91 of Act No. 40 of 2007 concerning Limited Liability Companies
} 
The Role and Position of Notaries in the Implementation of Circular Resolutions at the Foreign Owned Branch Company, PT. AR Packaging Indonesia

Decision making in a Limited Liability Company is normally made through the General Meeting of Shareholders. Provisions for the implementation of the GMS are carried out at the location where the company carries out its main business activities and as determined in the articles of association. Provided that the location of the GMS must be located and still within the territory of the Republic of Indonesia. That is, it cannot be justified if it is outside the territory of Indonesia's sovereignty. Under certain conditions, shareholders' decisions are made through Circular Resolutions.

Provisions regarding circular resolutions are regulated in Article 91 of Act No. 40 of 2007 concerning Limited Liability Companies (UUPT), which reads:

"Shareholders may also make binding decisions outside the GMS on condition that all shareholders with voting rights agree in writing by signing the proposal in question."

Based on the provisions of Article 77 of the Company Law, it has been regulated that the implementation of the GMS can be via video conference (where the GMS participants can see and hear each other directly and participate in the GMS), while still taking into account the quorum requirements and decision making as stated in the Articles of Association of the Limited Liability Company. The resolutions of the GMS must be made in the Minutes of the Meeting and signed by all GMS participants. If all shareholders have approved one hundred percent of the matters to be decided at the GMS, then Minutes of the GMS can be made circularly signed by all shareholders.

Notaries have a decisive and important role in the decision-making process of Limited Liability Companies, either through the General Meeting of Shareholders (GMS) or outside the GMS, namely Circular Decisions. This is because the Notary is a public official who is authorized to make authentic deeds and other authorities as referred to in the Company Law, including in the case of the GMS. Minutes of every GMS or Circular Decision must be made.

Minutes of the GMS or Circular Decisions which are then set forth in the form of a Notary deed can also be made by means of a Notary participating directly in attending the GMS activities. Thus, the Notary in the GMS witnessed and heard himself the process of the GMS, so that when he made the deed, the deed was an authentic deed.

For decision making by shareholders through Circular Resolutions, a notary is not required to be present when the event is being held. Circular Resolutions are 
made under the hands by making the minutes which are then followed by the making of the Deed of Statement of the Circular Decisions of the Shareholders. The mechanism for implementing the Circular Decision is as follows:

(1) Shareholders make a request for a Circular Resolution to be held to the board of directors by attaching the reasons for the need to make a Circular Resolution.

(2) The Board of Directors shall summon the shareholders no later than fifteen days after receiving the request from the shareholders. Summons are made by sending a Summons to the position of shareholders and summons by electronic mail (e-mail) to all shareholders by notifying the purpose and objectives of the Circular Decision.

(3) Circular decision meetings are held via video conference via the Microsoft Teams application

(4) The results of circular decisions are made in a Minutes by the Board of Directors. The Minutes of Circular Decisions shall be in Indonesian and English. Signed by all shareholders on stamp duty. In this case, one of the shareholders is outside the country of Indonesia, then the Minutes are sent to the position of the shareholder to be then signed and sent back to Indonesia.

(5) The Board of Directors brings the Minutes of the Circular Decision of the shareholders to the Notary for deed within a maximum period of 30 days from the date of the Circular Decision.

(6) Notary makes a deed and registers it with the Ministry of Law and Human Rights.

The position of the Notary appointed to make the deed of the Circular Decree of the Company can be selected from all over Indonesia. As long as the parties are facing the Notary. However, if a Notary is appointed to follow the process of implementing the Circular Decision, it must be a Notary who has the same position as the Limited Liability Company or may also have a different position but is still in the same province from the position of the Notary appointed to follow the Circular Decision of the Shareholders.

In the event that the shareholder is a foreign citizen. For this reason, the Notary is responsible for ensuring:

(1) That all shareholders agree, as evidenced by the signatures of the shareholders

(2) Checking that the Circular Decision is in accordance with the provisions of the UUPT 
(3) Since the shareholders are foreigners, who may not understand the Indonesian language, the Minutes of the Circular Decision Results are made in two languages, namely Indonesian and English.

(4) Receive a copy of the Minutes of the Resolution of the Shareholders' Meeting which has been stamped, in accordance with the provisions of Act No. 10 of 2020 concerning Stamp Duty

(5) Ensure the identity of the parties, in the event that the shareholders are foreigners. Need to request at least a photocopy of Passport. If the shareholder is temporarily in the territory of Indonesia for work, it is required to provide a photocopy of the Visa and Limited Stay Permit Card (KITAS).

(6) Registering the deed with the Ministry of Law and Human Rights

(7) Read the contents of the deed to all parties

3.2. The Process of Transferring Capital Status in a Limited Liability Company in Relation to the Company's Obligations

Based on Act No. 25 of 2007 concerning Investment, there are two status of capital:

\section{a. Domestic Investment (PMDN)}

are investment activities to conduct business in the territory of the Republic of Indonesia carried out by domestic investors using domestic capital;

\section{b. Foreign Investment (PMA)}

is an investment activity to conduct business in the territory of the Republic of Indonesia carried out by foreign investors, both those who use foreign capital wholly, and those who jointly with domestic investors.

For Domestic Investment (PMDN) the shareholders are one hundred percent Indonesian citizens. PMDN is the most popular form of business entity and the most widely used for various kinds of business activities in Indonesia. This form is considered to have the clearest legal basis and is considered one of the main choices for foreign investors who want to develop a business closed to foreign ownership.

Main Characteristics of PMDN:

(1) Entitled to run up to three lines of business

(2) Minimum capital for SIUP above IDR 50,000,000 
(3) Can become a KITAS sponsor (Limited Stay Permit Card)

(4) Have a minimum of two shareholders (Individual or Legal Entity)

(5) Company structure of at least two people (one Commissioner and one Director)

PMA (Foreign Investment) is the formation of business capital in the Republic of Indonesia aimed at foreign investors, using foreign capital fully or partially with domestic investors.

Before foreign investors decide to register PT. PMA in Indonesia, they must first investigate their business activities on the Negative Investment List (NIL) or the Negative Investment List (DNI), which contains the limits on foreign ownership in a predetermined business classification. NIL or DNI is issued and ratified by the Investment Coordinating Board (BKPM).

After the establishment of PT. PMA, the company needs to submit an Investment Activity Report (LAI) and also a Monthly Tax Report (LPB), even though the company still does not have activities and also tax dependents. In several aspects of its business, PT PMA still requires Indonesian citizens and Indonesian legal entities to be able to run their business. For example, the provisions regarding the limitation of share ownership by foreigners in the Negative Investment List as well as regarding the position of the director of personnel which is prohibited from being occupied by foreign workers as regulated in Presidential Regulation of the Republic of Indonesia (Perpes) Number 20 of 2018.

Limited Liability Company Capital Status, can be done through the initial establishment of a Limited Liability Company or through the process of transition from Domestic Investment (PMDN) status to Foreign Investment (PMA) through acquisition with Conditional Share Subscription And Purchase Agreement ) which is abbreviated as CSSPA. Then based on the CSSPA a Notary deed related to the Acquisition was made in accordance with Article 128 paragraph 2 of the Company Law.

\section{Closing}

Notaries have roles and responsibilities for the organs in a Limited Liability Company, one of which is the General Meeting of Shareholders (GMS). The GMS is held in the territory of Indonesia's sovereignty. In certain situations, where the conditions for holding the GMS cannot be met. In Act No. 40 of 2007 concerning Limited Liability Companies (UUPT) in Article 91, it is allowed to make decisions outside the GMS. Based on this, a Circular Resolution can be made with due regard to the implementation provisions in accordance with the Company Law. 
In making Circular Decisions, it is necessary to pay attention to the terms and time limits for summons, and the deadline for submitting the results of Circular Decisions, because if they do not pay attention to the stipulated time limit, Circular Decisions are considered to have not occurred and need to be repeated again. ma is the conclusion, the second paragraph contains suggestions. It is also necessary to pay attention to the position of the Notary appointed to participate in the implementation of the GMS or decision making outside the GMS (Circular Decisions).

\section{References}

Journals:

[1] A Chuasanga, Ong Argo Victoria. (2019). Legal Principles Under Criminal Law in Indonesia Dan Thailand, Jurnal Daulat Hukum, Vol 2, No 1 (2019) http://jurnal.unissula.ac.id/index.php/RH/article/view/4218

[2] Alam, Bahrul., \& Khisni, Akhmad. (2020). Legal Protection of Holders of Land Loss Data In The City Land Office of Kendari. JURNAL AKTA: Vol.7, No. 2, 159-164. Retrieved from http://jurnal.unissula.ac.id/index.php/akta/article/view/7963

[3] Arrohim, Mohammad B., \& Wahyuningsih, Sri Endah. (2020). Analysis of Judicial Application of Criminal Penalty Against Notary / Land Deed Officials Conducting Making Crime of the Fake Authentic Deed in State Court of Semarang. JURNAL AKTA: Vol.7, No. 2, 183-188. Retrieved from http://jurnal.unissula.ac.id/index.php/akta/article/view/7891

[4] Deen, Thaufiq., Ong Argo Victoria \& Sumain. (2018). Public Notary Services In Malaysia. JURNAL AKTA: Vol. 5, No. 4, 1017-1026. Retrieved from http://jurnal.unissula.ac.id/index.php/akta/article/view/4135

[5] Ong Argo Victoria, (2018) Waqf Al-Nuqūd In Indonesia (In Law Perspective), Jurnal Pembaharuan Hukum Vol 5, No 1 Universitas Sultan Agung, http://jurnal.unissula.ac.id/index.php/PH/article/view/2999

[6] Sukarmi, S., \& Victoria, A. (2018). Cash Waqf in Sustaining Of Indonesian Society "In Legal \&amp; Economic Perspective". AL-ITQAN: JOURNAL OF ISLAMIC SCIENCES AND COMPARATIVE STUDIES, 2(1), 83-97. https://doi.org/10.31436/al-itqan.v2i1.43

Books:

Budiarto Agus, (2002), Tanggung Jawab Pendirian Perseroan Terbatas, Jakarta: Ghalia

Regulation:

[1] Act No. 25 of 2007 concerning Investment 
[2] Article 91 of Act No. 40 of 2007 concerning Limited Liability Companies

[3] Government Regulation Number 8 of 2021 concerning the Company's Authorized Capital and Registration of Establishment, Amendment, and Dissolution of Companies that Meet the Criteria for Micro and Small Businesses

Internet:

Ade Irmansyah (2020) "Kronologi COVID-19 di Indonesia", Law Justice, url: https://www.law-justice.co/artikel/85525/sebenarnya-kapan-virus-coronapertama-kali-masuk-indonesia/ accessed on March 30, 2021 at 14:21 WIB. 